\title{
Contemplative Framework and Practices: An Islamic Perspective
}

\author{
Mohamed Safiullah Munsoor \\ University of Malaya, MMunsoor@isdb.org \\ Che Zarrina Sa'ari \\ University of Malaya, zarrina@um.edu.my
}

\begin{abstract}
Contemplative practices form the cornerstone of Islam and infiltrate every facet of life. These can be categorized into seven main types of practices, ranging from stillness through generative, ritual, activist, relational and creative to movement. Yet these practices are not very well known as compared to Buddhist meditation, Hindu yogic systems or Christian monastic practices. The 'tree of contemplative practices' was used within the Islamic context to map out seven main categories of practice derived from the divine scripture, as well as the words and practices of the Prophet and the Sages. There are five fundamental obligatory practices, as well as six voluntary ones, aimed at cultivating the mind-body and the soul. Stillness practices form a special category that includes self-introspection, reflection, re-collection, absorption and meditation. These stillness and generative practices represent two sides of the spectrum manifested as silence of speech and of the heart, as well as the generative or collective practices seen here to forge a platform of solidarity. In Islam, contemplation pervades every aspect of life, which repeatedly evokes the divine and therefore can be termed 'Living Meditation'. The key to these practices is to transcend one's self or ego and progress to higher levels of consciousness, thereby gaining proximity to the Lord and gaining contentment, which is the quintessence of Islam. The emerging data from neuro-science and contemplative practices points to an intricate link between them, with positive effects on mind and body. This fact then augments the inward sciences (tașawuf) of Islam, which has its own theoretical framework and groups of practitioners. This calls for integrating the tools and methods linked to these inward Islamic practices within the formal and non-formal educational systems, which forms one of the most potent entry points. This will enable these practices to develop from a very young age with a sense of awareness and meaning (instead of blind following of the faith), and will feed into developing spiritual and material well-being as the child matures, enabling to produce a more well-rounded human being. This is one of the steps for reducing aggressiveness and radicalisation, while mental space is created for a more tolerant society.
\end{abstract}

Keywords: contemplative, meditation, soul, Islam, Sufism 


\section{Introduction}

Contemplative practice is a key to building one's mind and body and overcoming the negative emotions or ruinous traits that plague human beings. In this sense, it forms the cornerstone of Islam, as the ensuing discussion demonstrates. Before delving into the practice itself, it is imperative to examine its main categorization and understand the framework within which it is embedded. The contemplative framework is presented as the tree of contemplative practices ${ }^{1}$ as shown in Figure 1: Islamic Contemplative Framework \& Practices below. This is presented as seven major branches, which can be condensed into three dimensions:

i) The practices where the mind and more specifically the heart predominate, namely, stillness and creative practices.

ii) Where the collective behaviour predominates, including generative and relational practices.

iii) Where the body predominates, including activist, movement and ritualistic practice.

The above practices represent a wide spectrum, embracing the mind-heart-body-relationships.

\section{The Fundamentals of Contemplative Practice}

The Jibrīl Hadìth ${ }^{2}$, signified by the visitation of Angel Jibrīl to Prophet Muhammad (p.b.u.h.), lays down the framework for the faith. During this visit, the Prophet was questioned on three fundamental aspects of Islam, and the Prophetic responses are outlined here: Islam that comprises the Five Pillars, the testimony of faith that there is no other God but God, which denotes a negation and an affirmation (Shahädatayn); pray five times a day (Salāt); give obligatory charity (zakāt); fast (sawm); and pilgrimage (hajj). Iman that comprises the Six Articles of Faith, belief in the Oneness of God; the angels; all the prophets; the divine scriptures; the Day of Judgment and pre-destination (al-

1 This has been modified based on The Centre of Contemplative Mind in Society, "The Tree of Contemplative Practices", last modified September 2007, http://contemplativemind.org/practices/tree.html.

${ }^{2}$ Ibn Daqiq al-'Id, A Treasury of Hadith: A Commentary on Nawawi's Selection of Forty Prophetic Traditions, trans. by Mokrane Guezzo (UK: Kube Publishing, 2014), 20-22. 
Qadā' wa al-Qadr). Ihsān that is interpreted as virtue and excellence in one's intention and actions.

Figure 1: Islamic Contemplative Framework \& Practices

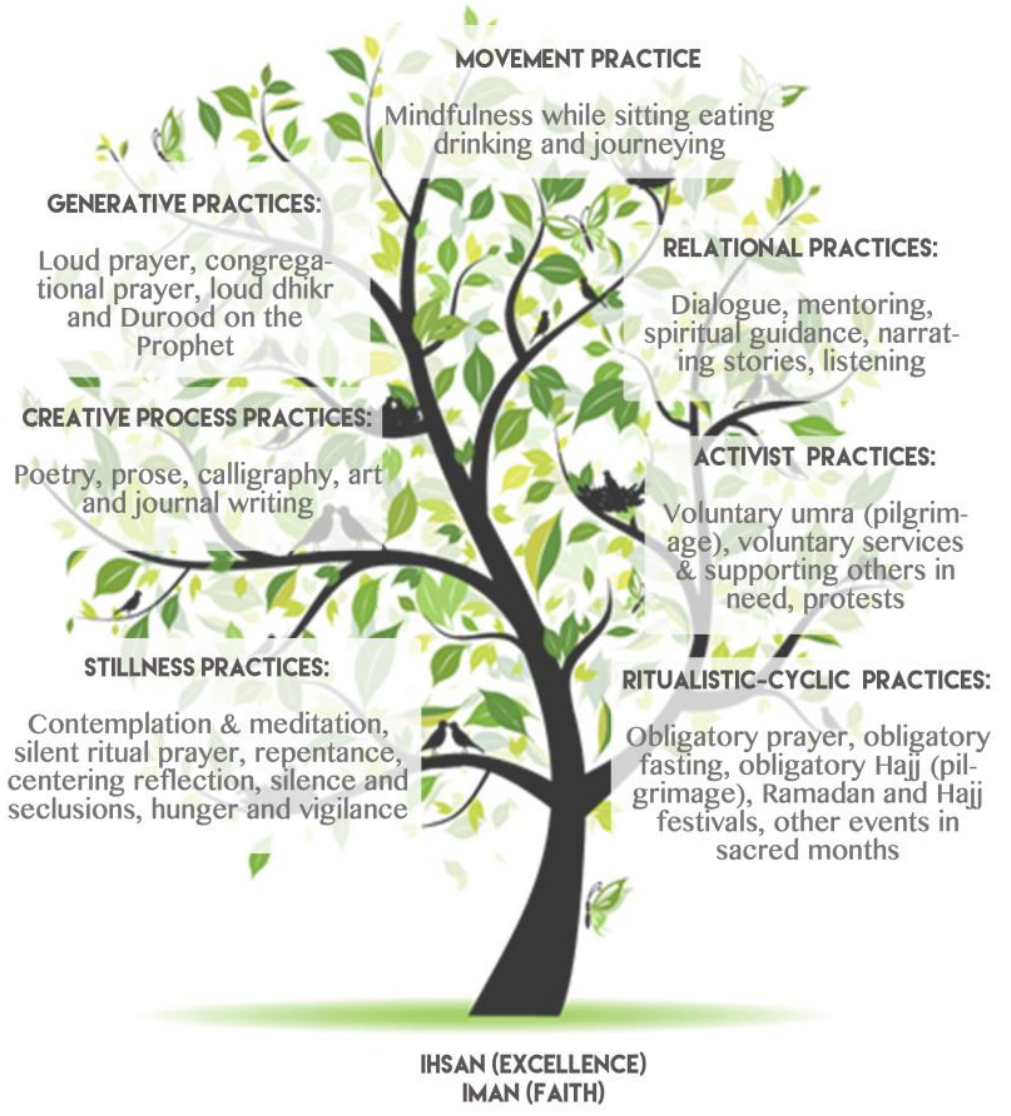

Source: Modified based on The Centre of Contemplative Mind in Society, "The Tree of Contemplative Practices"

The pivotal aspect of Islam is the Shahadah or the testimony of faith, which states that there is no other God but Allah and that Prophet Muhammad is His Prophet. The most critical belief is in the Oneness of God, which is called Tawhid. This forms the bedrock from which all else is derived, including all contemplative 
practices as shown in Figure 1. Shaykh Hamza Yusuf ${ }^{3}$ describes the Shahādah as having a vertical dimension through its connection with God; this is quintessential to Islam, where one is to fully surrender to God. The horizontal dimension, or Iman, with its inherent beliefs as described above, is the link to the chain of all prophets going back in time; and the dimension of depth, Ihsan is 'Worshipping God as if you see Him, while you do not see Him, He sees you. ${ }^{4}$ As will be noted, the other five pillars of Islam also form part of the contemplative practices under the ritualistic-cyclic practices as stated in Figure 1 above.

\section{Contemplative Practices in Islam}

As seen in Figure 1: The Tree of Contemplative Practices above, there is seven major branches, defined as Stillness, Generative, Creative Process, Relational, Activist, Ritualistic-Cyclic and Movement Practices. This categorization has been done based on the nature of the practices, each of which is expounded below:

Stillness: Focuses on quieting the mind and body, in order to bring about a state enabling one to turn to God. Within the Islamic framework, there are several elements that can be categorized under Stillness: contemplation, meditation, repentance, supplication, centring, reflection, thinking about death and silent ritual prayer.

In discussion, there is often confusion between contemplation and meditation. In Islam, contemplation appears repeatedly in the Qur'an, means, "And He has made the night and the day and the sun and the moon subservient (to His laws, so that they be of use) to you, and all the starts are subservient to His command: in this, behold, there are messages indeed for people who use their reason." ${ }^{5}$ This, means taking cognizance of things within you and without, which involves observation, reflection and internalization of human beings and their total environment including the celestial systems.

3 Hamza Yusuf, The Vision of Islam (California: Alhambra Productions Inc., 2002), CD No: 2.

4 Ibn Daqiq al-'Id, A Treasury of Hadith, 22.

5 Sürah al-Nahl 16:12; Muhammad Asad, The Message of the Quran (Kuala Lumpur: Islamic Book Trust, 2011), 472. 
Schuon $^{6}$ equates intellectualism with contemplation; he does this by framing it within the context of the unity of God and in relation to Islamic metaphysics, where he says that psychologically this is manifested in certitude (yaqin) in God and the serenity that arises therefrom.

Schuon ${ }^{7}$ cites al-'Alawi, who sums up that the profound meaning of religious practices and the reason they exist is for the remembrance of Allah, which means that all the shariah, all the dogmas and all the practices reside in the dhikr (remembrance of God).' Schoun ${ }^{8}$ describes the essence of meditation thus: 'To close the eyes is in fact to exclude the world, and to pronounce the Name is to affirm God.' This, he states, is excluding maya (artifice, illusion), while affirming atma (the real or true self) and closing the eyes is the nafi (negation) (la Ilaha) of the Shahädah; pronouncing the Name is the ithbāt (affirmation) (illa Allāh). This refers to creating a state of non-existence of oneself or of one's ego on one hand and the appearance of a sense of a Higher Being on the other.

Ibn 'Arabi discusses meditation in the context of spiritual unraveling saying, "We empty our hearts of reflective thinking, and we sit together with al-Haqq (The Real) on the carpet of adab (pious conduct) and muraqabah (spiritual attentiveness) and presence and readiness to receive whatever comes to us from Him - so that it is God who takes care of teaching us by means of unveiling and spiritual realization." 9 The seeker focuses on 'perfect collectedness in contemplation (murāqabah) and if God's grace persists then he may attain vision (mushāhadah). ${ }^{, 10}$

From another perspective, the Ignatian (Catholic) tradition ${ }^{11}$ defines meditation as an attempt made to understand God, while

6 Frithjof Schuon, Sufism: Veil and Quintessence: A New Translation with Selected Letters, edited by James. S. Cutsinger (Indiana: World Wisdom, 2006), 76.

7 Frithjof Schuon, Sufism, 146.

8 Frithjof Schuon, Sufism, 147, 177, 181.

9 James Winston Morris, The Reflective Heart: Discovering Spiritual Intelligence in Ibn Arabi's 'Meccan Illumination' (Louisville: Fons Vitae, 2005), 61.

10 Annemarie Schimmel, Mystical Dimensions of Islam (North Carolina: The University of North Carolina Press, Chapel Hill, 1975), 141.

11 Annunciation Trust, "Meditation and Contemplation", last accessed October 2008 , 
contemplation is the focus on a single symbol or word. AlGhazāli1 describes meditation as, "To keep one's thought towards God, the One who keeps watch over you and to keep all thoughts involved in Him." He adds that meditation results in the generation of knowledge about God (ma 'rifah), which impacts on both the body and the mind. Thus, al-Ghazāli ${ }^{13}$ points out that meditation is both a state of presence of mind of oneself and knowledge about God and he ${ }^{14}$ defines six stages of spiritual effort:

i) Mushāratah (taking account of passion): Making conditions to better oneself by purification of the soul (tazkiyah al-nafs), which forms the bedrock of the road to salvation. Allah says, means: "Indeed he succeeds who purifies it. And indeed he fails who corrupts it." ${ }^{15}$ When this verse was recited, the Prophet used to say, "O Allah! Give my soul what is good and You are its Guardian and Master, and the best to purify it. ${ }^{16}$ Al-Ghazāli ${ }^{17}$ says, one has to be careful to not become careless for even a moment especially with guarding one's eyes, ears, tongue, stomach, sexual organs, hands and feet. Thus, he says, one needs to instruct them 'to save the soul from these sins.' 18

ii) Murāqabah (deep meditation) ${ }^{19}$ : The essence here is to "worship God as if you see him and while you see him not He sees you" ${ }^{20}$. Imam al-Ghazali uses the term 'meditation' in connection with three introspective types of action:

a. Sincerity (ikhlās) in relation to virtuous action and purity of intention,

b. Examination of one's sinful actions and repentance,

c. Observance of rules and laws in relation to lawful action.

http//www.annuciationtrust.org.uk/approaches/meditation_contemplation.shtm 1.

${ }^{12}$ Imam Ghazzali, Ihya Ulum-Id-Din (The Book of Religious Learning), trans. by F. Karim (New Delhi: Islamic Book Services, 1995), 3:395.

${ }^{13}$ Imam Ghazzali, Ihya Ulum-Id-Din, 3: 395.

${ }^{14}$ Imam Ghazzali, Ihya Ulum-Id-Din, 3: 391.

${ }^{15}$ Sürah al-Shams, 91:9, Ibn Kathīr, Tafsīr Ibn Kathīr (Abridged) (Riyadh: Darussalam, 2003), 10:498.

${ }^{16}$ Ibn Kathīr, Tafsīr Ibn Kathīr, 10:499. Al-Tabarani recorded that Ibn 'Abbās said the Prophet said this verse.

${ }^{17}$ Imam Ghazzali, Ihya Ulum-Id-Din, 3:391.

${ }^{18}$ Imam Ghazzali, Ihya Ulum-Id-Din, 3: 391-393.

${ }^{19}$ Imam Ghazzali, Ihya Ulum-Id-Din, 3: 399-400.

${ }^{20} \mathrm{Ibn}$ Daqīq al-'Īd, A Treasury of Hadith, 20-22. 
iii) Muhasabah (taking account of oneself) ${ }^{21}$ : Taqwa or piety refers to obeying Allah's orders and refraining from what $\mathrm{He}$ has forbidden, being accountable for one's deeds before being recompensed, while being mindful of the good deeds for the next life ${ }^{22}$. Caliph 'Umar' ${ }^{23}$ said, "Take account of your action before accounts are taken from you and weigh actions before they are weighed upon", while the sage Hasan al-Basri ${ }^{24}$ says, "A believer takes guard over oneself".

iv) $M u$ 'aqabah (punishment of oneself) ${ }^{25}$ : Punishing oneself as a result of bad conduct or intention. This involves doing the opposite of the bad act or reprimanding oneself for the act performed. It also offers opportunities to gift things that one possesses or offer self-sacrifice by fasting or performing other acts of worship.

v) Mujāhadah (exerting efforts) ${ }^{26}$ : Exerting effort and conducting oneself against one's dictates, that is where sins move far away from you. The female sage Sha'unah says, "There are two safeguards at the time of your final exit from this world, namely, to keep sorrow attached to your heart and place the love of God above any temptation. ${ }^{27}$ This entails the striving of the soul in the way of God, constantly fighting against one's lower desires to attain the pleasure of the Almighty.

vi) $M$ ' $^{\prime}$ atabah (self-rebuke) ${ }^{28}$ : Al-Ghazāli stresses that there is no greater enemy than one's own baser self (nafs), which, if left unrestrained will lead one to evil and ultimately the destruction of his soul. The nafs is like a wild animal, which without harsh discipline cannot be tamed. It must be rebuked frequently and brought into submission before the will of Allah, thus transforming it into the self-accusing soul.

As seen from the six categories above, meditation within Islam is a fluid concept, which al-Ghazāli ${ }^{29}$ articulates as having

\footnotetext{
${ }^{21}$ Imam Ghazzali, Ihya Ulum-Id-Din, 3:400-401.

${ }^{22}$ Sūrah al-Hashr 59:18. Ibn Kathīr, Tafsīr Ibn Kathīr, 10:573.

${ }^{23}$ Imam Ghazzali, Ihya Ulum-Id-Din, 3: 399-400.

${ }^{24}$ Imam Ghazzali, Ihya Ulum-Id-Din, 3: 400.

${ }^{25}$ Imam Ghazzali, Ihya Ulum-Id-Din, 3: 402-405.

${ }^{26}$ Imam Ghazzali, Ihya Ulum-Id-Din, 3: 405.

${ }^{27}$ Imam Ghazzali, Ihya Ulum-Id-Din, 3: 418.

${ }^{28}$ Imam Ghazzali, Ihya Ulum-Id-Din, 3: 420.

${ }^{29}$ Imam Ghazzali, Ihya Ulum-Id-Din, 3: 397.
} 
two key factors. Firstly, there is the act before the action, which refers to the intention of the seeker, verifying if one is doing it for the sake of God, for human dictates or at the prompting of the devil. Thus, 'Verily works are according to one's intentions, and each person is (gets) what he intends', as the Prophet Muhammad $^{30}$ stated. In a similar vein, Prophet Jesus ${ }^{31}$ outlined: an action which is especially good, follow it; an action which is especially bad, avoid it; and an action which is difficult to ascertain, as to its goodness or badness, entrust it to one who knows it. The second key factor is one's state of mind during the action, in relation to which three questions have been asked: "How have you done it?' 'Why have you done it?' 'For whom have you done it?" ${ }^{2}$ This, then, ascertains if it was done according to permissible means and that the act was performed not to show off but sincerely for God.

The term 'meditation' within Islam refers to the final query by Angel Jibril to the Prophet, "What is Excellence (Ihsān)?", to which the Prophet responded, "Worshipping God as if you see Him (mushahadah), while you see Him not, he sees you (muraqabah)'. In this case, the aspirant is in a state of focusing on God, with the intention of the Lord turning towards him. This takes two forms, the silent remembrance (dhikr al-khafi) and the loud remembrance (dhikr al-lisan), where the focus is on one single attribute of God.

There is sound evidence in the Qur'ān to support the need for a meditative mind, as indicated here, means:

i) "God (Allah) watches you". 33

ii) "Does he not know that God sees him and hears his word?"34

iii) "And remember your Lord within yourself, humbly and with fear and without loudness in words in the mornings and in the afternoons ..."

Ibn al-Mubārak ${ }^{36}$ commenting on "Allah watches over you" says this refers to keeping the thought in mind as if you are seeing

\footnotetext{
${ }^{30}$ Ibn Daqiq al-'Id, A Treasury of Hadith, 15-16.

${ }^{31}$ Imam Ghazzali, Ihya Ulum-Id-Din, 3: 398.

${ }^{32}$ Imam Ghazzali, Ihya Ulum-Id-Din, 3: 397-398

${ }^{33}$ Sürah al-Nisā' 4:1. Ibn Kathīr, Tafsīr Ibn Kathīr, 10:370.

${ }^{34}$ Sūrah al- 'Alaq 96:14, Ibn Kathīr, Tafsīr Ibn Kathīr, 10:536.

${ }^{35}$ Sürah al-A 'rāf 7:205. Ibn Kathīr, Tafsīr Ibn Kathīr, 10:248-249.

${ }^{36}$ Imam Ghazzali, Ihya Ulum-Id-Din, 3: 393.
} 
God, while Ibn `Ata' says, "Constant meditation over truth is good divine service" ${ }^{, 37}$. Meditation is not done for its own sake but to develop the state of one's heart or soul, to transcend from one state to another and to enable one to get closer to God. In this light, seven progressive stages are mapped out by the seeker in the spiritual path, as shown in Figure 2: The Stages of Meditative Progression \& Consciousness below.

Reflection (taffakur) is another type of meditation, which is more cognitive, is reflection on the creation and created things. This is one of the central themes in both the divine scripture and the Prophetic tradition. Ibn 'Arabi's ${ }^{38}$ writing on Islam unfolds this spiritual intelligence, which comprises experience, reflection and right action, which together form a framework for comprehending the Divine. Several Qur'Énic verses urge one to reflect, means:

i) "And among His wonders is this: He creates for you mates out of your own kind. So that you might incline towards them, and He engenders love and tenderness between you: in this, behold, there are signs indeed for people who reflect!"39.

ii) "Have they not travelled through the land, and have they hearts wherewith to understand and ears wherewith to hear? Verily, it is not the eyes that grow blind, but it is the hearts which are in the breasts that grow blind" ${ }^{\prime 4}$.

iii) "And $\mathrm{He}$ has made the night and the day and the sun and the moon subservient [to His laws, so that they be of use] to you; and all the stars are subservient to His command: in this, behold, there are messages indeed for people who use their reason!"41

Ibn 'Arabī discusses four transformative pillars as shown in Table 1: Four Pillars of Knowledge below: silence, seclusion, hunger and vigilance, which in effect are all stillness practices. These four transformative pillars are comprehended by the aspirant (murid) and by the one who is more advanced in knowledge, called the verifier (muhaqqiq) according to the own

\footnotetext{
${ }^{37}$ Imam Ghazzali, Ihya Ulum-Id-Din, 3: 337.

${ }^{38}$ James Winston Morris, The Reflective Heart, 6.

${ }^{39}$ Sūrah Yūsuf 12:109. Ibn Kathīr, Tafsīr Ibn Kathīr, 5: 221-223.

${ }^{40}$ Sürah Hajj 22:46. Ibn Kathīr, Tafsìr Ibn Kathīr, 6: 590-592.

${ }^{41}$ Sūrah al-Ankabūt, 29:20. Ibn Kathīr, Tafsīr Ibn Kathīr, 7: 475-476.
} 
states (hal) and stations (maqām) of consciousness, and also in reference to a particular domain of divine knowledge ( $m a$ ' $r$ ifah $)^{42}$.

Table 1: Four Pillars of Knowledge

\begin{tabular}{|c|c|c|c|c|}
\hline \multirow{2}{*}{$\begin{array}{l}\text { The Four } \\
\text { pillars } \\
\text { (arkān) }\end{array}$} & \multicolumn{2}{|c|}{ Spiritual states } & \multirow{2}{*}{$\begin{array}{l}\text { Spiritual } \\
\text { stations and } \\
\text { secrets } \\
\text { (maqāmat } \\
\text { /asrār) }\end{array}$} & \multirow[t]{2}{*}{$\begin{array}{l}\text { Domains } \\
\text { of } \\
\text { knowledge } \\
\text { (ma'ārif) }\end{array}$} \\
\hline & $\begin{array}{l}\text { For the } \\
\text { aspirant } \\
\text { (murid } \\
\text { /salik) }\end{array}$ & $\begin{array}{l}\text { For the } \\
\text { verifier } \\
\text { (muhaqqiq } \\
\text { /muqarrab) }\end{array}$ & & \\
\hline $\begin{array}{c}\text { Silence } \\
(\text { Samt })\end{array}$ & $\begin{array}{c}\text { Safety from } \\
\text { harm }\end{array}$ & $\begin{array}{l}\text { Intimate } \\
\text { converse }\end{array}$ & $\begin{array}{c}\text { Inspiration } \\
\text { (wahy) }\end{array}$ & $\begin{array}{c}\text { God } \\
\text { (Allāh) }\end{array}$ \\
\hline $\begin{array}{c}\text { Seclusion } \\
\text { ('Uzlah) }\end{array}$ & \multicolumn{2}{|c|}{ Transcendent of all attributes } & $\begin{array}{c}\text { Divine Unity } \\
\text { (wahdaniyyah) } \\
\text { \& Uniqueness } \\
\text { (ahadiyyah') }\end{array}$ & $\begin{array}{c}\text { This world } \\
(\text { dunyā })\end{array}$ \\
\hline $\begin{array}{l}\text { Hunger } \\
\left(J \bar{u}^{\prime}\right)\end{array}$ & $\begin{array}{c}\text { Humility, } \\
\text { submission, } \\
\text { servility, } \\
\text { lack of self- } \\
\text { importance, } \\
\text { calm, } \\
\text { indigence, } \\
\text { absence of } \\
\text { base } \\
\text { thoughts }\end{array}$ & $\begin{array}{c}\text { Delicacy of } \\
\text { feeling, } \\
\text { serenity, } \\
\text { intimacy, } \\
\text { non- } \\
\text { worldliness, } \\
\text { transcendence } \\
\text { of ordinary } \\
\text { humanness }\end{array}$ & $\begin{array}{c}\text { Eternal Self- } \\
\text { Subsistence } \\
\text { (hamadaniyyah) }\end{array}$ & $\begin{array}{c}\text { Satan } \\
(\text { shaytạn })\end{array}$ \\
\hline $\begin{array}{l}\text { Vigilance } \\
\text { (Sahar) }\end{array}$ & $\begin{array}{l}\text { Cultivating } \\
\text { the moment }\end{array}$ & $\begin{array}{l}\text { Cultivating } \\
\text { the moment, } \\
\text { assuming } \\
\text { lordly } \\
\text { attributes }\end{array}$ & $\begin{array}{l}\text { Everlasting } \\
\text { Self-Existence } \\
\text { (qayyimiyyah) }\end{array}$ & $\begin{array}{c}\text { The self } \\
\text { (nafs) }\end{array}$ \\
\hline
\end{tabular}

Source: Muhyiddin Ibn Arabi Ibn 'Arabī, The Four Pillars of Spiritual Transformation, 22-23.

${ }^{42}$ Muhyiddin Ibn 'Arabī, The Four Pillars of Spiritual Transformation: The Adornment of the Spiritually Transformed (Hilyat al-Abdal), trans. and ed. by Stephen Hirtenstein. (Oxford: Anqa Publishing, 2008), 22-23. 
Stillness Practices: Regarding silence (samt) and seclusion ('uzlah), Abī Hurayrah narrates that the Prophet says, "Whoever believes in God and the Last Day, let him say what is good, or let him be silent." ${ }^{43}$ Similarly, al-Qushayri ${ }^{-44}$ says silence is security but points out that it is, concurrently, important to command what is good and forbid evil although one needs to be silent in the presence of God. Ibn 'Arabi ${ }^{45}$ and al-Qushayr ${ }^{-46}$ articulate two types of silence, namely, the outer and the inner. The first is the silence of the tongue, where one does not speak except about God, while the silence of the heart is where one refrains from any thoughts about created things. In the first case, the burden of the person is lightened, while the latter is a speaker of wisdom. When both the tongue and the heart are silent then one's innermost consciousness (sirr) becomes apparent and the Lord gets closer to the person ${ }^{47}$.

Seclusion is linked with silence, given that when one withdraws from human company then silence sets in. Seclusion can be categorized firstly as physical seclusion from others and this belongs to the aspirant. The second type is having no contact with created things in one's heart and this is of the verifier, which comes from deep contemplation. This is called witnessing or mushähadah, 'what the heart retains of the form of the One contemplated." ${ }^{48} \mathrm{Ibn}$ "Arabi ${ }^{49}$ states that if this is done on a sustained basis, it can lead to grasping the mysteries of Divine Unity (wahdāniyyah), where it brings the quality of uniqueness (ahadiyyah), as outlined in the Table 1 below. Seclusion bequeaths knowledge of this world, says Ibn 'Arabi ${ }^{50}$ Al-Qushayri ${ }^{51}$ outlines a distinguishing factor between seclusion ('uzlah) and retreat (khalwah), where 'uzlah refers to detaching from humankind,

\footnotetext{
${ }^{43}$ Abu-l-Qasim' Abd'al-Karim bin Hawazin al-Qushayri, The Risalah: Principle of Sufism, trans. By Rabia Harris, ed. by Laleh Bakhtiar \& Seyyed Hossein Nasr (Chicago: Great Books of the Islamic World Inc, 2002), 147.

${ }^{44}$ Abu-l-Qasim' Abd'al-Karim bin Hawazin al-Qushayri, The Risalah, 147.

${ }^{45}$ Muhyiddin Ibn Arabi, The Four Pillars of Spiritual Transformation, 32-35.

${ }^{46}$ Abu-l-Qasim' Abd'al-Karim bin Hawazin al-Qushayri, The Risalah, 147.

${ }^{47}$ Muhyiddin Ibn Arabi, The Four Pillars of Spiritual Transformation, 33.

${ }^{48}$ Muhyiddin Ibn Arabi, The Four Pillars of Spiritual Transformation, 34.

${ }^{49}$ Muhyiddin Ibn Arabi, The Four Pillars of Spiritual Transformation, 35.

${ }^{50}$ Muhyiddin Ibn Arabi, The Four Pillars of Spiritual Transformation, 53.

${ }^{51}$ Abu-l-Qasim' Abd'al-Karim bin Hawazin al-Qushayri, The Risalah, 126
} 
while the second is gaining intimacy with God. For him seclusion is not mere physical isolation but separating blameworthy qualities and replacing them with thoughts of the Divine, while being amongst people.

Regarding hunger $(j \bar{u})$ and vigilance (sahar), these two are linked, since hunger leads to vigilance ${ }^{52}$. Ibn 'Arabī distinguishes hunger not necessarily as an empty belly but a longing for something, while vigilance means being awake or refraining from something, but on a deeper level having perpetuity. Al-Qushayrī uses the term murāqabah instead of sahar to mean a state of witnessing or watchfulness of God's presence, but they essentially have the same meaning. He adds that preservation of this knowledge of the consummate awareness of God is essential in cultivating it and forms the foundation of good action. This, he says, cannot be accomplished unless one empties oneself through a process of self-observation and inner accounting (muhasabah). ${ }^{53}$ There are two forms of hunger: firstly, voluntary hunger, which is that of the seekers and secondly, obligatory (involuntary) hunger, which is that of the verifiers or more advanced students of knowledge. Hunger has spiritual states and stations; for the seeker it includes humility, submission, indigence, discretion, tranquil emotions and an absence of base thoughts, and for the verifiers it is characterized by delicacy of feelings, serenity, intimacy (with God), disappearance of worldliness and transcendence of ordinary human characteristics through the Lord. The last represents the station of eternal self-subsistence (maqām al-hamadanī), where the Lord provides openings for the verifiers. He says that 'hunger bequeaths the knowledge of Satan, may God preserve us and you from him. ${ }^{54}$

Vigilance is the fruit of hunger, for an empty stomach drives away sleep. As in the case of hunger, vigilance also has two types. The first is the eye's vigil, which aims to maintain the spiritual intention in the heart aimed at pursuing the quest. Secondly, the vigil of the heart is the state of awakening from the state of

\footnotetext{
${ }^{52}$ Muhyiddin Ibn Arabi, The Four Pillars of Spiritual Transformation, 35.

${ }^{53}$ Al-Qushayri, The Risalah, 229.

${ }^{54}$ Muhyiddin Ibn Arabi, The Four Pillars of Spiritual Transformation, 36.
} 
forgetfulness and seeking contemplation. "Vigilance bequeaths knowledge of the self," says Ibn "Arabī. ${ }^{55}$

Generative Practices: The intent here is to forge a platform for evoking common thoughts and feelings through acts of devotion and prayers. The congregational prayers (which are highly valued and firmly encouraged) is where the loud recitation from the Qur'ān forms a point of focus of three out of the five ritual obligatory prayers. The weekly Friday sermon forms an established generative practice largely focusing on the current social and cultural issues of society that need to be addressed. The collective recitation of peace on the Prophet and loud zikr (remembrance of God) offers a devotional platform for generating energy and forging solidarity.

Creative Process Practices: As with other traditions, the art and architecture of Islam has been heavily influenced by the religion, however they differ from most others in that traditionally, figurative art has been excluded. Rather, the creative process focuses on the beauty of God's creation through geometry and floral forms inspired by nature. The repetitive geometric shapes and symmetry that have become a hallmark of Islamic art and architecture, with their aesthetic sense and tranquillity provide the ambience for the mind to be oriented towards the infinite. Poetry and prose have formed a rich tradition within Islam within both the Arab and Persian regions; more specifically the mystical tradition, expressed through the likes of Jalaluddin Rumi, Omar Khayyam, Ghalib, Firdows, Ibn 'Arabī and others, who have used the medium to create awareness of and orient people's mind towards God. They speak of the connection between man and God and create a longing in the hearts of man to draw closer to their Creator.

Relational Practices: these Islamic traditional practices include the relationship between a sheikh or spiritual teacher and a seeker and this takes the forms of dialogue, mentoring and spiritual guidance. This is generally linked to conduct within the confines of the law called Shari'ah and more specifically the development of the inward state or the self. This practice, termed tașawwuf is a science of self-development within Islam and it has been preserved within some societies and lost in others. Given the

\footnotetext{
${ }^{55}$ Muhyiddin Ibn Arabi, The Four Pillars of Spiritual Transformation, 38.
} 
oral traditions of the Arab, African and Asian cultures, narrating and listening to stories and asking questions about it has been a lasting tradition, although current technology is fast replacing it with television, where humans are passive recipients.

Activist Practices: This largely covers those actions done outwardly that benefit oneself and others, including service to others and protests for justice. Service to others forms a core part of Islam, both in the context of helping those in need sadaqah (voluntary giving) and zakat (obligatory giving) and benefiting them; this enables one to overcome one's selfishness and rise above one's ego, which is central to Islam.

Ritualistic or Cyclic Practices: This essentially comprises the five pillars of Islam, including declaration of faith; performing the obligatory prayers; giving obligatory charity; fasting; and performing pilgrimage if one can afford it. Given that the shahadah has already been discussed, the other four pillars will be outlined here:

i) Prayer: The ritual prayer which is performed five times a day, was a command given to the Prophet in his meeting with God in the seventh heaven, highlighting its importance as a pivotal aspect of faith. When one examines it in the light of the tree of contemplative practices, one can identify the following characteristics: It is a stillness practice since the majority of the prayer is done in silent contemplation. The Prophet used to be silent during the first part of the ritual prayer, when inquired about his silence, he replied that he used it for supplication as follows: "O Allah, remove my sins from me as far as You have removed the East from the West. O Allah, purify me from sins as a white garment is purified from filth. O Allah, wash away my sins with water, snow and hail". ${ }^{56}$ One of the most recommended voluntary acts is the 'tahajjud' prayer as highlighted in sūrah al-Isrā' 17:79. This prayer is performed during the last third of the night, the most still period of the day. As Rabī'ah al-'Adawiyyah said, "Oh Lord: The Stars are shining and the eyes of man are closed and kings have shut their doors and every lover is alone with his beloved and

${ }^{56}$ Ruqaiyyag Waris Maqsood, The Muslim Prayer Encyclopedia: A Complete Guide to Prayers as Taught by the Prophet Muhammad (New Delhi: Goodword Books, 1998), 50. 
here am I alone with Thee." ${ }^{57}$ General vigilance needs to be observed throughout the prayers rhythmic movement, for excessive movement nullifies the prayer. This inculcates the principle of 'the still body instils a still mind'. This in effect represents movement meditation with set patterns and contemplative focus. Generative practice, since congregational prayers are a platform for people to get together and it is reinforced through prayer recitals. This is strongly encouraged as a basis for solidarity as well as spiritual cohesion. A narration of the Prophet supports this, means: "A faithful believer to another faithful believer is like bricks in a wall, supporting each other. While (saying this) he clasped his hand and interlaced his fingers". ${ }^{58}$ Activist practice, since there are many voluntary or supererogatory prayers, which are done as additional spiritual activities. These are important in their own sense since the five daily prayers are done out of a sense of obligation, with the understanding that they are a duty which must be performed, while voluntary prayers are done out of love for God. Schuon ${ }^{59}$ captures the canonical prayer as a centrepiece when he says, "The prayer integrates man into the rhythm of universe adoration and through the ritual orientation of the prayer towards the 'kaaba' into its centripetal order". This movement of prayer then gives it a unified global force of worship of God both in space and time, connecting people from all walks of life and forms a repetitive cycle across the variations in time between countries.

ii) Zakāt: This is an important facet of Islam, which not only entails obligatory parting with a defined portion of your wealth, but more crucially parting with your desire to retain it. Schuon points out that zakät and sadaqah vanquish egoism and avarice and actualize the solidarity of all creatures, for alms are a fasting of the soul, even as the obligatory fast (Ramaḍann) is an almsgiving of the body. ${ }^{60} \mathrm{He}$ further adds that almsgiving is detachment with regards to the world. ${ }^{61}$ Imam al-Ghazali ${ }^{62}$ states

\footnotetext{
${ }^{57}$ Alexander Knysh, Islamic Mysticism: A Short History (Leiden \& Boston: Brill, 2010), 29.

${ }^{58}$ Ruqaiyyag Waris Maqsood, The Muslim Prayer Encyclopaedia, 70.

${ }^{59}$ Frithjof Schuon, Understanding Islam (Indiana: World Wisdom, 1998), 33.

${ }^{60}$ Frithjof Schuon, Understanding Islam, 33.

${ }^{61}$ Frithjof Schuon, Sufism, 116.

${ }^{62}$ Imam Ghazzali, Ihya Ulum-Id-Din, 3:186-188.
} 
that zakat is the 'purification of properties' and it has three main causes for being a pillar of Islam:

a. Appreciating the oneness of God and abiding with His decree and that 'Promise reaches perfection when a Unitarian has got no object of love except the One.'

b. Miserliness is the trigger to destruction, as the Prophet says, 'There are three destructive guilt's - to obey miserliness, to follow lower desires and self-conceit. For the Lord says "those who are saved from miserliness have got salvation" given that it purifies the self and one's material possessions.

c. Expressing gratitude for the gifts of God, which are innumerable, ranging from one's body and mind, to all of the material and non-material things.

iii) Fasting: This consists of fasts both during Ramaḍān or obligatory and voluntary fasts. Al-Ghazāli ${ }^{63}$ states, "Fasting is half of patience and patience is half of faith." This is one of the unique acts of worship which is hidden from people, where one does not necessarily see another doing it. Therefore, there is no inherent riy $\bar{a}^{\prime}$ (pride) in it. Schuon ${ }^{64}$ asserts that fasting is detachment with regards to desire, hence with regards to ego and fasting cuts man off the continual and devouring flux of carnal life, introducing into the flesh a kind of death and purification. Similarly Ibn 'Arabi ${ }^{65}$ emphasizes that eating to satisfaction tends to provide more energy to the limbs, which causes it to commit a string of actions, taking one away from the main aim and intention of worshipping God.

iv) Hajj: This is an obligatory act, if one can afford it, Schoun mentions the pilgrimage is the return to the Centre, the Heart, the Self ${ }^{66}$ and it is a prefiguration of the inward journey towards the Ka'bah of the heart and purifies the community, just as the circulation of the blood, passing through the heart, purifies the body. ${ }^{67}$

Movement Practices: In Buddhism, movement meditation is part of various forms of meditation and it is taught to the monks

\footnotetext{
${ }^{63}$ Imam Ghazzali, Ihya Ulum-Id-Din, 3:202.

${ }^{64}$ Frithjof Schuon, Understanding Islam, 33.

${ }^{65}$ Ibn Arabi, The Four Pillars of Spiritual Transformation, 46.

${ }^{66}$ Frithjof Schuon, Sufism, 116.

${ }^{67}$ Frithjof Schuon, Understanding Islam, 34-35.
} 
and the laymen. In Islam, there is no conscious teaching of it in the present day, with some exceptions, even though meditation forms the very core of Islam. Being mindful of what one is doing, as well as saying prayers or uttering God's remembrance, are part and parcel of Islam. Presence of mind in prayers and daily living infiltrates every aspect of the life of a Muslim and this awareness of God is the cornerstone of worship. Thus, God consciousness is the central theme and it is part of bodily movements, which become basic to stop the movements of the mind. ${ }^{68}$

\section{The Direction and Impact of Contemplative Practices}

There are two distinct benefits derived from contemplative practices. The first is the emerging data from neuro-science ${ }^{69}$ on the positive effects of spiritual practices, ranging from ritual prayers to remembering God or meditation (dhikr) to fasting. From a scientific perspective, these scientific data sets are from various religions and more recently from practices within Islam; ${ }^{70}$ all point to physiological and psychological changes that lead to a sense of well-being.

Secondly, the experiential data generated from individuals' experiences of these spiritual practices and their sense of wellbeing and meaning generated by these practices. Here, we touch only upon the former, while focusing on the spiritual impact of

${ }^{68}$ Imam Ghazzali, Ihya Ulum-Id-Din, 3: 202.

${ }^{69}$ Daniel Goleman, "Tibetan \& Western Models of Mental Health," in Mind Science: An East-West Dialogue, edited by Daniel Goleman \& Robert A. F. Thurman (Boston: Wisdom, 1990), 95; Jensine Andresen, "Meditation Meets Behavioral Medicine: The Story of Experimental Research on Meditation," in Cognitive Models and Spiritual Maps: The Interdisciplinary Explorations of Religious Experience, edited by Jensine Andrews \& Robert K. C. Forman (Thorveton: Imprint Academic, 2000), 21-29; Alberto Chisea, "Vippassana Meditation: Systematic Review of Current Evidence," in Journal of Alternative and Complementary Medicine 16, no. 1 (2010): 37-46.

${ }^{70}$ F. Ibrahim, W. Abu Bakar, W. Abas \& N. S. Cheok, Salat: Benefit from Science Perspective (Kuala Lumpur: University of Malaya, 2008), 11-111; F.Ibrahim,.., \& W. W. Ahmad et al., "Study of Heart Rate Changes in Different Salah Positions," in Journey of Physical Therapy Science, 25, no. 211-214 (2013), 687-690; H. Doufesh, T. Faisal, K. S., Lim \& F. Ibrahim, "EEG Spectral Analysis on Muslim prayers," in Applied Psychophysiology and Biofeedback, 37, no.1 (2012): 11-18; Z.E.M. Afifi, "Daily Practices, Study Performance and Health During the Ramadan fast," in The Journal of the Royal Society for the Promotion of Health, 117, no. 4 (1997): 231-235. 
these practices and their frame of reference. Suffice to say that there is a whole framework within Islam called tasawwuf', or 'inward science', which has a wealth of theory and groups of practitioners. Here only some essential aspects are drawn upon to give a snapshot of its framework for developing the self.

Contemplative practices are generated through obligatory acts of worship, voluntary acts of love and seeking closeness to Him. God essentially does not benefit from our worship but it is our prescription for developing ourselves and overcoming our inherent and acquired weaknesses. In the light of this, seven stages have been conceptualized by the Sages, with references from the Qur'ān, as represented in Figure 2 below. These practices are generally done under a Shaykh or Master, who not only teaches how it is to be done but also observes the aspirants and guides them through a combination of demonstration, lectures, one-to-one counselling, spiritual guidance and techniques of reflection and non-formal education. This type of learning is what can be termed as experiential learning, which is validated through a series of dialogues and observations both by the Shaykh and his/her peers.

The weakness of the soul and its progressive ascension in the first three main stages, what Margret Smith ${ }^{71}$ calls Muhasibi's psychological theory, are:

i) Nafs al-ammārah bi al-sü': The lower soul (nafs) represents the seat of appetites and of passion, the 'flesh' with its sinful lusts. This leads one to sinful states while striving for one's own self-interest. Al-Muhāsibī ${ }^{72}$ alerts us to the nature of the nafs whereby, if one gives in to it, it will lead him in a downward spiral to the death of his spiritual self, while leaving it alone will take one to its own dictates and he comes under its control. AlMuḥāsibī says, "Place it where God Almighty placed it and describe it as He described it and withstand it according to His command, for it is a greater enemy to you than Satan (IblÊEs) himself, and IblÊs gains power over you only by means of it and your consent to it." $" 73$

\footnotetext{
${ }^{71}$ Margaret Smith, Al-Muhasibi: An Early Mystic of Baghdad (Lahore: Islamic Book Foundation, 1935), 90-91.

${ }^{72}$ Margaret Smith, Al-Muhasibi, 91.

${ }^{73}$ Margaret Smith, Al-Muhasibi, 90 .
} 
ii) Nafs al-Lawwamah: Al-Muhāsibī suggests that the ${ }^{74}$ lower soul is akin to the beast of burden, which needs to be tamed, and therefore needs a variety of disciplines, so that it can serve the immediate master, which will then enable the person to serve the Ultimate Master. At this stage, the soul struggles with its desires and there is self-critical inquiry; with discipline over time, the soul starts to take the upper hand and becomes a reproachful soul. In this light, the Lord says means, "But nay I call to witness the accusing voice of man's conscience!" 75 Asad ${ }^{76}$ adds that man's reproaching soul is the subconscious awareness of his own shortcomings and failings.

iii) Nafs al-Mutma'innah: Once the soul becomes reproachful, the higher nature has taken over and it is in a better position to wage war successfully against the lower soul. This is where human nature is seen at its best, 'the soul at rest'. At this juncture, the 'lust of the flesh' is no longer an issue and 'the soul has become a captive, in complete submission to the Will of it Lord', while becoming the 'soul at rest'. In this context, the Lord says, means, "(But unto the righteous God will say,) $O$ thou human being that has attained to inner peace! Return thou unto thy Sustainer, well-pleased (and) pleasing (Him): enter, then, together with My (other true) servants - yea, enter thou My paradise!",77

\footnotetext{
${ }_{75}^{74}$ Margaret Smith, Al-Muhasibi, 91.

${ }^{75}$ Sürah al-Qiyāmah 75:2.

${ }^{76}$ Muhammad Asad, The Message of the Quran, 109.

${ }^{77}$ Sürah al-Fajr , 89:27-30.
} 
Figure 2: The Stages of Meditative Progression \& Consciousness ${ }^{78}$
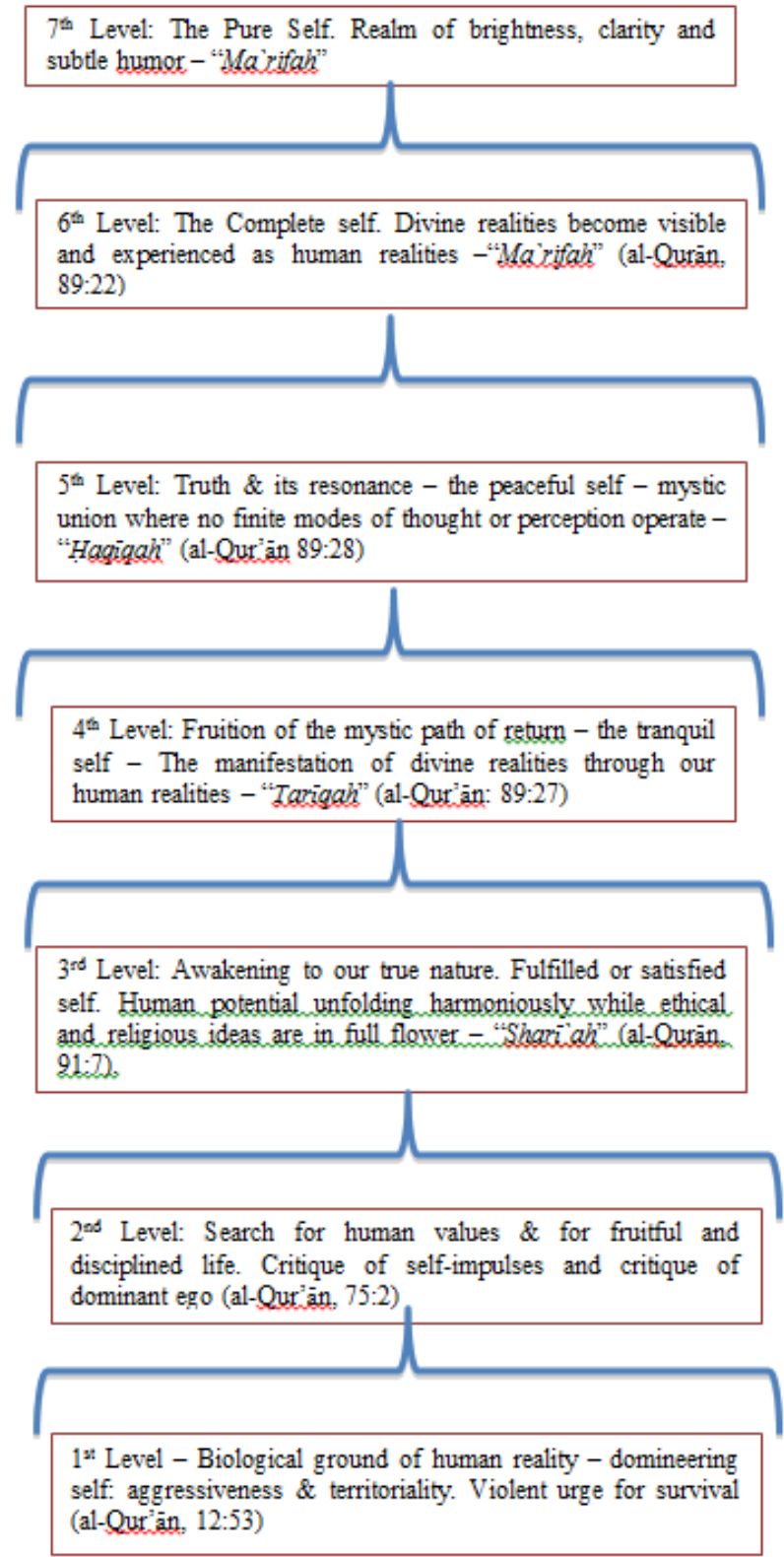

${ }^{78}$ Chisthi, "The Stages of the development of the Soul", last modified $2^{\text {nd }}$ October 2007, http:/www.chisthi.ru/soul_development.htm. 


\section{Discussion and Conclusion}

The terms 'contemplation' and 'meditation' have generally been used interchangeably to mean the same. The dictionary defines contemplation ${ }^{79}$ as the act of contemplating; thoughtful observation or full or deep consideration; reflection; religious contemplation. Meditation ${ }^{80}$ means the act of meditating, continued or extended thought; reflection; contemplation; transcendental meditation, devout religious contemplation or spiritual introspection. As defined above, there is hardly a difference between these two terms.

Within Islamic thought, the Qur'ān frequently refers to contemplation of the signs of God both within oneself and externally. While in Islamic literature itself the words 'contemplation' and 'meditation' have been used interchangeably, a distinction can be drawn. Contemplation refers to being mindful and reflecting (tafakkur) on the signs and attributes of God, as well as recollection (tadhakkar) of them. Meditation (murāqabah), meanwhile, has a deeper sense, meaning movement from the stage of contemplation to absorption, where one tries to witness God (mushāhadah) or, failing that, that God sees him (murāqabah). There are numerous groups within Islam with their own methods of remembrance of God; this can take many forms, depending on the group, from loud pronouncements to one where silence is used either by itself or by using one's breath as a point of attention. This process is accompanied by emptying the mind of everything other than God and a state of absorption in Him, as done by the Prophet during his retreats at Mount Hira' for 13 years, prior to receiving Prophet hood. Al-Shādhilīi ${ }^{81}$ best captures the essence of this when he says:

You who wander in deserts away from your own consciousness,

Come back to yourself to find all existence summed up in you,

\footnotetext{
79 Dictionary.com, s.v. "Contemplation," accessed April $8^{\text {th }}$, 2014,http://dictionary.reference.com/browse/contemplation?s=t
Dictionary.com, s.v. "Meditation," April $8^{\text {th }}$, 2014,http://dictionary.reference.com/browse/meditation?s=t

${ }^{81}$ Edward Jabra Jurji, Illumination in Islamic Mysticism (Princeton: Princeton University Press, 1938).
} 
You are the way and reality of perfection.

One in whom the great consciousness of God dwells.

Every act is an act of worship done in a state of witnessing the Presence of God, and this is the most recommended of states, in line with the Qur'ānic injunction, "Worship me sitting, standing and sleeping. ${ }^{" 82}$ In order to deepen one's consciousness of God, several methods have been outlined including rigorous training and meditative practices with their inherent discipline of hunger, vigilance, silence and seclusion. In this light, there is a difference between the Islamic and Ignatian (Catholic) traditions of the word 'meditation.' The Ignatian understanding of contemplation is rooted in the imagination of God and in this sense is more cognitive. ${ }^{83}$ In the Islamic context, meditation is a state of absorption (khush $\bar{u}$ ), while contemplation is focusing on an attribute of God, and the emphasis in both cases is on the heart. The similarity between the two traditions, however, is the focus on God, even though the point of divergence is the concept of Trinity within the Christian context.

In the Buddhist tradition, meditation essentially refers to quietening the mind through following the flow of the breath (anabaena sati), with deep reflection on oneself, or a process of introspection (vippasana). While both aspects are a part of Islam in terms of quietening one's mind, being aware that God is observing you (murāqabah), reflection of the signs of God (taffakur), introspection and the witnessing of divine manifestations (mushāhadah) gives an orientation that is completely different. In Buddhism there is no concept of God the Creator as such and the focus is not on a Supreme Being but on the self ${ }^{84}$.

In the Hindu tradition, the yogic system manifests various kinds of physical postures symbolizing movement meditation and mental states evoked by breathing and focus on symbols and the breath. This, in principle, seems common to Islam in the light of

${ }^{82}$ Sürah Āli- 'Imrān, 3:191.

83 Ignation Spirituality, "Ignation Contemplation: Imaginative Prayer", last modified http://www.ignatianspirituality.com/ignatian-prayer/the-spiritualexercises/ignatian-contemplation-imaginative-prayer

${ }^{84}$ Dalai Lama, Mind Science: An East Meets West Dialogue (Boston: Wisdom Publications, 1991), 13. 
the Islamic ritualistic prayers but fundamentally different in Hinduism's orientation of having multiple symbols and gods.

Why contemplate or meditate? The fundamental reason for contemplative practice is that it helps one to become fully aware of oneself and one's behavior towards God and also others. Thus, there are clear profits derived from contemplation and meditation and this is well articulated in the Qur' ān, where the Lord says means, "Consider the human self, and how it is formed in accordance with what it is meant to be, and how it is imbued with moral failings as well as with consciousness of God. To a happy state shall indeed attain he who causes this (self) to grow in purity, and truly lost is he who buries it (in darkness). ${ }^{.85} \mathrm{Asad}^{86}$ commenting on these verses points out, firstly, that the concept of self means not only the physical aspect but also the whole being with its essence of life. Secondly, he points out the concept of moral free will, whereby man can choose to rise to great heights of consciousness (taqwāhāa) or to debase himself and become lowly (fujürahō').

The question of why we should do these contemplative practices at all is answered by al-Ghazālī He captures six spiritual processes, ranging from taking account of one's passion and the purification of the soul (mușarahah), to deep meditation with the knowledge that God is always watchful of you (murāqabah); taking account of yourself through self introspection (muhāsabah); self-punishment or doing the opposite of what is intended (ти'āqabah); exerting efforts against the dictates of one's lower self (mujāhadah), overcoming and rebuking the base self (mu'a'tabah), so that the ego becomes deflated. Each one is aimed at taming the ego or self, as al-Muhāsibī articulates, taming the beast of burden so that it turns its orientation towards God.

Likewise, Ibn 'Arabī articulates four pillars of spiritual transformation paired together: hunger-vigilance and silenceseclusion. These are aimed at overcoming the lower, base desires and transforming the self into spiritual actualization. Hunger allows one to curb the desire (nafs). The desire for food frequently leads one to over-eat, with negative implications in the long term. Fasting is seen to bring about a state of heightened awareness,

\footnotetext{
${ }^{85}$ Sürah al-Shams 91:7-10.

${ }^{86}$ Muhammad Asad, The Message of the Quran, 1141-1142.
} 
which aids spiritual activities and brings about a state of vigilance. Vigilance is congruent with meditation and with the modern day use of mindfulness or a state of witnessing without undue discrimination or evaluation. Silence refers to both that of the tongue and, more importantly, to the silence of the heart, when the focus of thought is none other than God. Seclusion is the silence of the heart, where it is not only physical seclusion from people, but also the higher state which means being amidst the crowd but at the same time fully mindful of the Lord, in other words, being present while being absent.

These above four are enablers as articulated by Ibn 'Arabī; they empower the seeker to 'tame the beast' or lower base desires, as Imam al-Muhasibi articulates, and move upwards into the seven levels of consciousness as shown in Figure 2 above. Within the Islamic perspective, effort is very important but they alone are insufficient to make spiritual progress. In this sense, the Prophet refers to two concepts, namely, trust in God (tawakkul), where one exerts effort and then puts trust in God, and God's mercy (rahmah), the light that shines on the heart to liberate it.

The tree of contemplative practices indicates the wide repertory available within Islamic practices that fit into the seven categories shown in Figure 2. The five pillars are subsumed within ritualistic practices, while the voluntary practices, born out of love and/or fear, constitute the other categories. As evident, there is a plethora of practices ranging from activist, relation and generative rituals to stillness and creative practices. Although the ritualistic practices are obligatory, spiritual progression generally occurs in those who involve themselves in voluntary practices. There is special reference and attention given to stillness practices within Islam and this is supported both by the divine scriptures and the words and actions of the Prophet. In this light, the essence of Islam is being mindful and having the consciousness of God in whatever one does, which is a state of meditative awareness and living.

The most critical factor is the role of the teacher or the spiritual master, who has attained a certain level of selfactualization and who is able to both teach and guide the aspirants. There are still traditional organizations where these types of experimental learning take place, most of which do not necessarily promote themselves. However, given the context of modern 
society, where people have high levels of anxiety, stress, violence and diseases associated with eating disorders, these types of spiritual practices could be integrated into the education system at different levels. There is a need to adopt the format, tools and methods of learning that have a neurological effect which impacts the well-being of individuals and groups undergoing such learning. The schema of the development of the self, with its concepts, methods and tools, calls for integrating these into formal and informal education, so that students can access this realm of knowledge at a very early age. These practices not only have an impact on their well-being but also enhance their character under the tutelage of a sheikh or master. This, then forms the inward sciences of Islam, which aims to develop the whole individual similar to other esoteric traditions in other faiths.

\section{References}

Al-'Id, Ibn Daqiq. A Treasury of Hadith: A Commentary on Nawawi's Selection of Forty Prophetic Traditions, trans. by Mokrane Guezzo. UK: Kube Publishing, 2014.

Andresen, Jensine. "Meditation Meets Behavioral Medicine: The Story of Experimental Research on Meditation," in Cognitive Models and Spiritual Maps: The Interdisciplinary Explorations of Religious Experience, ed. by Jensine Andrews Robert K \&. C. Forman. Thorveton: Imprint Academic, 2000.

Annunciation Trust, "Meditation and Contemplation", last accessed October 2008, http//www.annuciationtrust.org.uk/approaches/meditation_conte mplation.shtml.

Asad, Muhammad. The Message of the Quran. Kuala Lumpur: Islamic Book Trust, 2011.

Chisea, Alberto. "Vippassana Meditation: Systematic Review of Current Evidence," in Journal of Alternative and Complementary Medicine 16, no. 1 (2010): 37-46.

Chisthi, "The Stages of the development of the Soul", last modified 2nd October 2007, http:/www.chisthi.ru/soul_development.htm.

Dictionary.com, s.v. "Contemplation," accessed April 8th, 2014,http://dictionary.reference.com/browse/contemplation?s=t 
Dictionary.com, s.v. "Meditation," accessed April 8th, 2014,http://dictionary.reference.com/browse/meditation?s=t

F. Ibrahim, W. Abu Bakar, W. Abas \& N. S. Cheok, Salat: Benefit from Science Perspective. Kuala Lumpur: University of Malaya, 2008

F.Ibrahim \& W. W. Ahmad et al., "Study of Heart Rate Changes in Different Salah Positions," in Journey of Physical Therapy Science, 25, no. 211-214 (2013), 687-690.

Goleman, Daniel. "Tibetan \& Western Models of Mental Health," in Mind Science: An East-West Dialogue, edited by Daniel Goleman \& Robert A. F. Thurman. Boston: Wisdom, 1990.

H. Doufesh, T. Faisal, K. S., Lim \& F. Ibrahim, "EEG Spectral Analysis on Muslim prayers," in Applied Psychophysiology and Biofeedback, 37, no.1 (2012): 11-18

Hawazin al-Qushayri, Abu-1-Qasim' Abd'al-Karim bin. The Risalah: Principle of Sufism, trans. By Rabia Harris, ed. by Laleh Bakhtiar \& Seyyed Hossein Nasr. Chicago: Great Books of the Islamic World Inc, 2002.

Ibn 'Arabī, Muhyiddin. The Four Pillars of Spiritual Transformation: The Adornment of the Spiritually Transformed (Hilyat al-Abdal), trans. and ed. by Stephen Hirtenstein. Oxford: Anqa Publishing, 2008.

Ibn Kathīr, Tafsīr Ibn Kathīr (Abridged). Riyadh: Darussalam, 2003).

Ignation Spirituality, "Ignation Contemplation: Imaginative Prayer", last modified http://www.ignatianspirituality.com/ignatian-prayer/thespiritual-exercises/ignatian-contemplation-imaginative-prayer

Imam Ghazzali. Ihya Ulum-Id-Din (The Book of Religious Learning), trans. by F. Karim. New Delhi: Islamic Book Services, 1995.

Jurji, Edward Jabra. Illumination in Islamic Mysticism. Princeton: Princeton University Press, 1938.

Knysh, Alexander. Islamic Mysticism: A Short History. Leiden \& Boston: Brill, 2010.

Lama, Dalai. Mind Science: An East Meets West Dialogue. Boston: Wisdom Publications, 1991. 
Schimmel, Annemarie. Mystical Dimensions of Islam. North Carolina: The University of North Carolina Press, Chapel Hill, 1975.

Schuon, Frithjof. Sufism: Veil and Quintessence: A New Translation with Selected Letters, edited by James. S. Cutsinger. Indiana: World Wisdom, 2006.

Schuon, Frithjof. Understanding Islam. Indiana: World Wisdom, 1998.

Smith, Margaret. Al-Muhasibi: An Early Mystic of Baghdad. Lahore: Islamic Book Foundation, 1935.

The Centre of Contemplative Mind in Society, "The Tree of Contemplative Practices", last modified September 2007, http://contemplativemind.org/practices/tree.html.

Waris Maqsood, Ruqaiyyag. The Muslim Prayer Encyclopedia: A Complete Guide to Prayers as Taught by the Prophet Muhammad. New Delhi: Goodword Books, 1998.

Winston Morris, James. The Reflective Heart: Discovering Spiritual Intelligence in Ibn Arabi's 'Meccan Illumination'. Louisville: Fons Vitae, 2005.

Yusuf, Hamza. The Vision of Islam. California: Alhambra Productions Inc., 2002.

Z.E.M. Afifi, "Daily Practices, Study Performance and Health During the Ramadan fast," in The Journal of the Royal Society for the Promotion of Health, 117, no. 4 (1997): 231-235. 
Safiullah and Zarrina, Contemplative Framework and Practices 